PENELITIAN

\title{
Pengaruh Simvastatin Terhadap Kadar Nitric Oxide Makrofag Mencit Balb/C yang Diberi Lipopolisakarida
}

\author{
Taufik Eko Nugroho*, Mohamad Sofyan Harahap*, Heru Dwi Jatmiko* \\ *Bagian Anestesiologi dan Terapi Intensif FK Undip/ RSUP Dr. Kariadi, Semarang
}

\section{ABSTRACT}

Background: Nitric oxide (NO) has a potential role in pathogenesis of systemic hypotension in septic shock. Endotoxin will increases NO release which influenced of proinflamatory cytokine. Simvastatin suppresses endotoxin induced proinflamatory cytokines production as a result of lipopolysaccharides, so the NO production can be inhibited.

Objective: to prove the effect of simvastatin 0,03 $\mathrm{mg} ; 0,06 \mathrm{mg}$ and 0,12 $\mathrm{mg}$ peroral on intraperitoneal cause NO level on Balb/c mice with intraperitoneal injection of lipopolysaccharide become lower.

Methods: a randomized post test only controlled group laboratoric experimental studied on 20 male Balb/c mice divided into 4 groups and injected intraperitoneally with lipopolysaccharide 20mg/kg and 6 hours later were gived simvastatin. K1 as the control group ; K2, K3, and K4 administrered with simvastatin 0,03 mg;0,06 mg; and $0,12 \mathrm{mg}$ peroral. NO was taken from peritoneal macrophage culture and observed by Griess method. The results were analyzed by ANOVA and post hoc statistical assays.

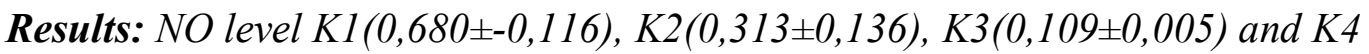
$(0,091 \pm 0,011)$. There were significant decrease in NO level between $K 2, K 3$ and $K 4$ than $K 1(p<0,05)$. There were no significant difference in NO level between $K 2$ than $K 3$ and $K 4$ ( $p=0,001)$, also between $K 3$ and $K 4(p>0,05)$.

Conclusion: Simvastatin significantly lowernitric oxide level in mice intraperitoneal macrophages .

Keywords: simvastatin, lipopolysaccharide, nitric oxide.

\section{ABSTRAK}

Latar belakang: Nitric oxide (NO) berperan dalam patogenesis terjadinya hipotensi sistemik pada syok septik. Pajanan endotoksin akan menyebabkan peningkatan pelepasan NO yang dipengaruhi oleh aktivasi sitokin proinflamasi. Simvastatin diduga menekan produksi sitokin proinflamasi akibat pajanan lipopolisakarida (LPS), sehingga pembentukan NO dapat dihambat.

Tujuan: Membuktikan pengaruh pemberian simvastatin dosis 0,03 mg, 0,06 mg dan 0,12 mg peroral dapat menyebabkan kadar NO mencit yang diberi lipopolisakarida intraperitoneal menjadi lebih rendah.

Metode: Penelitian eksperimental laboratorik dengan desain randomized post test 
only controlled group pada 20 ekor mencit Balb/c yang disuntik lipoplisakarida intraperitoneal dan simvastatin dosis 0,03 mg; 0,06 mg dan 0,12 mg peroral. Mencit dibagi menjadi 4 kelompok secara random, yaitu K1 sebagai kontrol, K2 yang mendapat simvastatin 0,03 mg, K3 yang mendapat simvastatin 0,06 mg, dan K4 yang mendapat simvastatin 0,12 mg. Pemeriksaan NO diambil dari kultur makrofag intraperitoneal setelah 6 jam pemberian simvastatin dengan metode Griess. Uji statistik yang digunakan adalah parametrik ANOVA dan dilanjutkan uji Posteriori.

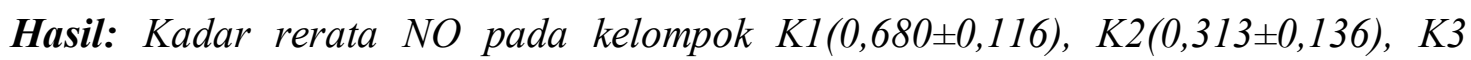
$(0,109 \pm 0,005)$ dan $K 4(0,091 \pm 0,011)$. Terdapat penurunan yang bermakna kadar NO pada kelompok K2, K3 dan K4 dibanding K1 dengan $p<0,05$. Tidak terdapat perbedaan yang bermakna antara kadar NO kelompok K2 dengan kelompok K3 dan $K 4$, serta kelompok $K 3$ dibanding $K 4(p>0,05)$.

Simpulan: Simvastatin secara bermakna dapat menyebabkan kadar NO makrofag intraperitoneal mencit yang diinduksi lipopolisakarida menjadi lebih rendah.

Kata kunci: simvastatin, lipopolisakarida, nitric oxide (NO).

\section{PENDAHULUAN}

Sepsis menimbulkan angka kematian yang cukup tinggi pada manusia. Angka mortalitas yang tinggi akibat sepsis menyebabkan sepsis sebagai masalah kesehatan dunia. Sepsis merupakan penyebab utama kematian pada pasien kritis di Amerika. ${ }^{1,2}$ Jumlah penderita sepsis di Amerika pada tahun 2000 mencapai 750.000 orang dan menyebabkan lebih dari 210.000 pasien meninggal tiap tahunnya. ${ }^{3}$ Angka kematian akibat sepsis antara 30\% sampai $40 \%{ }^{2}$ Syok septik dan kegagalan multiorgan akibat sepsis menyebabkan outcome yang buruk bagi penderita. ${ }^{1}$ Sepsis sebagian besar disebabkan oleh bakteri gram negatif dengan persentase $60 \%$ sampai $70 \%$ kasus. ${ }^{4,5}$ Bakteri gram negatif dapat melepaskan suatu substansi yang dapat menstimulasi sel imun, sehingga sel tersebut terpacu untuk melepaskan mediator inflamasi. ${ }^{2,4,5}$ Substansi bakteri yang berperan penting pada keadaan sepsis tersebut adalah lipopolisakarida., ${ }^{3,5}$ Lipopolisakarida (LPS) ialah suatu komponen utama membran terluar bakteri gram negatif yang merupakan salah satu faktor patogenik sepsis dan dikatakan sebagai penyebab sepsis terbanyak. ${ }^{2,4,5}$

Respons sistemik tubuh akibat LPS menyebabkan aktivasi Nuclear Factor$\kappa B$ (NF-кB), yang merupakan salah satu protein faktor transkripsi pada makrofag. ${ }^{2,5}$ Aktivasi NF-kB akan 
meningkatkan produksi mediatormediator inflamasi atau sitokin proinflamasi seperti tumor necrosis factor (TNF), interleukin (IL) serta interferon gamma (IFN- $\gamma){ }^{4,5}$ Peningkatan mediator - mediator inflamasi ini akan memacu peningkatan produksi nitric oxide (NO) dalam jumlah besar melalui aktivasi inducible Nitric Oxide Synthase (iNOS). ${ }^{5}$ iNOS dapat diekspresikan oleh sejumlah tipe sel imun terutama makrofag. ${ }^{2,4,5}$

Nitric oxide (NO) adalah molekul biologi yang bisa terdapat di seluruh tubuh, dihasilkan oleh sejumlah tipe sel yang berkaitan dengan proses penyakit, dan dapat menimbulkan efek di tingkat seluler dan vaskuler. ${ }^{6}$ NO mempunyai peran penting dalam patogenesis sepsis, dimana akibat pengaruh dari iNOS, NO akan diproduksi dalam jumlah besar oleh makrofag, sel hepar maupun pada endotel pembuluh darah. ${ }^{6,7}$

Golongan statin adalah obat yang efektif dan ditoleransi dengan baik untuk mengobati dislipidemia. ${ }^{8,9}$ Statin juga dikenal sebagai obat yang merupakan inhibitor kuat pada proses inflamasi. ${ }^{10,11}$ Mekanisme statin dalam menyebabkan modulasi respon imun merupakan hal yang kompleks, akan tetapi dikatakan tidak berkaitan dengan efeknya dalam menurunkan kolesterol LDL. ${ }^{9,11,12}$

Pada penelitian ini pajanan LPS dilakukan terhadap mencit dengan penyuntikan intraperitoneal, karena pada intraperitoneal terdapat banyak makrofag yang merupakan tipe sel spesifik untuk iNOS yang dipicu oleh LPS. ${ }^{13,14}$ Pemeriksaan kultur makrofag untuk pemeriksaan NO pada penelitian ini dilakukan pada 6 jam pasca penyuntikan LPS karena TNF- $\alpha$ dan IL-1 dari mencit akan mengalami peningkatan mulai dari 2 jam dan mencapai puncaknya pada 8 jam pasca penyuntikan LPS, serta konsentrasi statin plasma mencapai puncak dalam 1 hingga 4 jam pasca pemberian simvastatin..$^{9,15,16}$

Penelitian tentang efek statin terhadap kadar NO belum banyak dilakukan. Statin dalam terapi mempunyai beberapa dosis bertingkat. ${ }^{15}$ Penelitian ini dilakukan untuk mengetahui pengaruh pemberian simvastatin terhadap kadar NO makrofag pada mencit, dengan menggunakan dosis bertingkat yaitu 10 $\mathrm{mg}, 20 \mathrm{mg}$ dan $40 \mathrm{mg}$ pada manusia, yang kemudian dikonversikan ke dalam dosis mencit dengan berat badan $20 \mathrm{~g}$ menjadi $0,03 \mathrm{mg}, 0,06 \mathrm{mg}$ dan $0,12 \mathrm{mg}$ 
setelah pemberian LPS.

\section{METODE}

Penelitian ini termasuk eksperimental laboratorik dengan desain post test only controlled group dengan tujuan mencari pengaruh pemberian simvastatin peroral pada mencit yang diberi lipopolisakarida intraperitoneal terhadap kadar NO makrofag intraperitoneal. Sampel penelitian 20 ekor mencit balb/c jantan, umur $8-10$ minggu, berat $20-30$ gram, sehat dan tidak tampak cacat secara anatomi. Mencit dibagi dalam 4 kelompok perlakuan, sampel yang memenuhi kriteria inklusi diadaptasikan dengan dikandangkan per kelompok dan diberi pakan standar serta minum yang sama selama 1 minggu secara ad libitum. Kelompok dibagi menjadi 4 yaitu kelompok kontrol (K1), Perlakuan 1 (K2), Perlakuan 2 (K3), Perlakuan 3 (K4). K1 adalah kelompok kontrol, dimana mencit disuntik LPS intraperitoneal $10 \mathrm{mg} / \mathrm{KgBB}$ dan mendapat $\mathrm{NaCl} 0,9 \%$ peroral. $\mathrm{K} 2$ adalah kelompok perlakuan 1, dimana mencit disuntik LPS intraperitoneal $10 \mathrm{mg} /$ $\mathrm{KgBB}$ dan mendapat simvastatin 0,03 mg peroral. K3 adalah kelompok perlakuan 2, dimana mencit disuntik
LPS intraperitoneal $10 \mathrm{mg} / \mathrm{KgBB}$ dan mendapat simvastatin $0,06 \mathrm{mg}$ peroral. K4 adalah kelompok perlakuan 3, dimana mencit disuntik LPS intraperitoneal $10 \mathrm{mg} / \mathrm{KgBB}$ dan mendapat simvastatin $0,12 \mathrm{mg}$ peroral. Setelah ditunggu selama 6 jam kemudian dilakukan pengambilan dan kultur makrofag intraperitoneal. Selanjutnya dilakukan pengukuran kadar NO makrofag intraperitoneal. Masingmasing kelompok dilakukan pemeriksaan kadar NO supernatan kultur makrofag intraperitoneal. Kadar NO dari tiap-tiap kelompok perlakuan dihitung dengan menggunakan metode modifikasi Gries dari Green et al dan Ding et al. Kadar NO makrofag dibaca dengan alat ELISA reader, kemudian hasilnya dihitung menggunakan persamaan regresi linier. Kajian Etik (Ethical clearance) telah mendapat persetujuan Komisi Etik Penelitian Kesehatan FK Undip/RSDK dengan nomor 147/EC/FK/ $\mathrm{RSDK} / 2012$.

\section{HASIL}

Hasil pengamatan rerata kadar NO makrofag intraperitoneal pada keempat kelompok menunjukkan kadar NO yang berbeda yaitu pada kelompok perlakuan 3 (K4) menunjukkan kadar NO yang 
paling rendah dibandingkan kelompok kontrol (K1), seperti ditampilkan pada Tabel 1.

Gambar 1 menunjukkan uji normalitas dengan Shapiro-Wilk test untuk mengetahui sebaran data. Pada penelitian didapatkan data berdistribusi normal $(\mathrm{p}=0,583)$ sehingga uji beda dilakukan dengan ANOVA dilanjutkan dengan uji homogenitas varian untuk menentukan jenis uji posteriori. Hasil uji homogenitas varian dilihat dari output Levene test. Nilai $\mathrm{p}$ pada Levene test menunjukkan nilai $0,006(\mathrm{p}<0,05)$. Hal ini berarti varian data pada ketiga kelompok tersebut adalah tidak homogen. Untuk mengetahui kelompok mana yang memiliki perbedaan, maka dilakukan uji posteriori dengan uji Tamhane untuk melihat beda antara kelompok K2, K3, dan K4 dengan kelompok K1 serta antara kelompok K2, K3 dan K4. Uji dianggap bermakna apabila $\mathrm{P}<0,05$.

Uji beda dilakukan untuk mengetahui apakah ada perbedaan yang bermakna kadar NO makrofag intraperitoneal pada kelompok kontrol (K1), kelompok perlakuan 1 (K2) dan kelompok perlakuan 2 (K3) dan kelompok perlakuan 3 (K4). Uji beda ini dilakukan dengan menggunakan ANOVA dan dilanjutkan dengan uji posteriori. Hasil uji one way-Anova menunjukkan hasil signifikan $(\mathrm{p}=0,001)$ dengan interpretasi bahwa didapatkan perbedaan bermakna dari dua kelompok penelitian atau lebih.

Uji korelasi dilakukan untuk mengetahui apakah terdapat korelasi yang bermakna antara dosis pemberian simvastatin dengan kadar NO makrofag intraperitoneal pada kelompok penelitian. Uji ini dilakukan menggunakan uji Pearson. Dari hasil uji korelasi didapatkan korelasi yang bermakna $(p=0,001)$, dengan nilai koefisien korelasi Pearson sebesar 0,881 yang menunjukkan bahwa arah korelasi negatif dengan koefisien korelasi kuat.

Dari hasil uji posteriori didapatkan bahwa kadar NO makrofag intraperitoneal pada kelompok K1 (kontrol) dibanding dengan masingmasing kelompok perlakuan (K2, K3, K4) terdapat perbedaan bermakna dengan nilai $p<0,05$. Tidak terdapat perbedaan yang bermakna antara kadar NO makrofag intraperitoneal pada kelompok perlakuan K2 dibandingkan kelompok perlakuan K3 $(p=0,158)$, 
Tabel 1. Kadar nitrit oksida pada kelompok kontrol dan kelompok perlakuan $(\boldsymbol{\mu M})$

\begin{tabular}{cccc}
\hline Kelompok & N & Mean & SD \\
\hline K1 & 5 & 0,680 & 0,116 \\
K2 & 5 & 0,313 & 0,136 \\
K3 & 5 & 0,109 & 0,005 \\
K4 & 5 & 0,091 & 0,011 \\
\hline
\end{tabular}

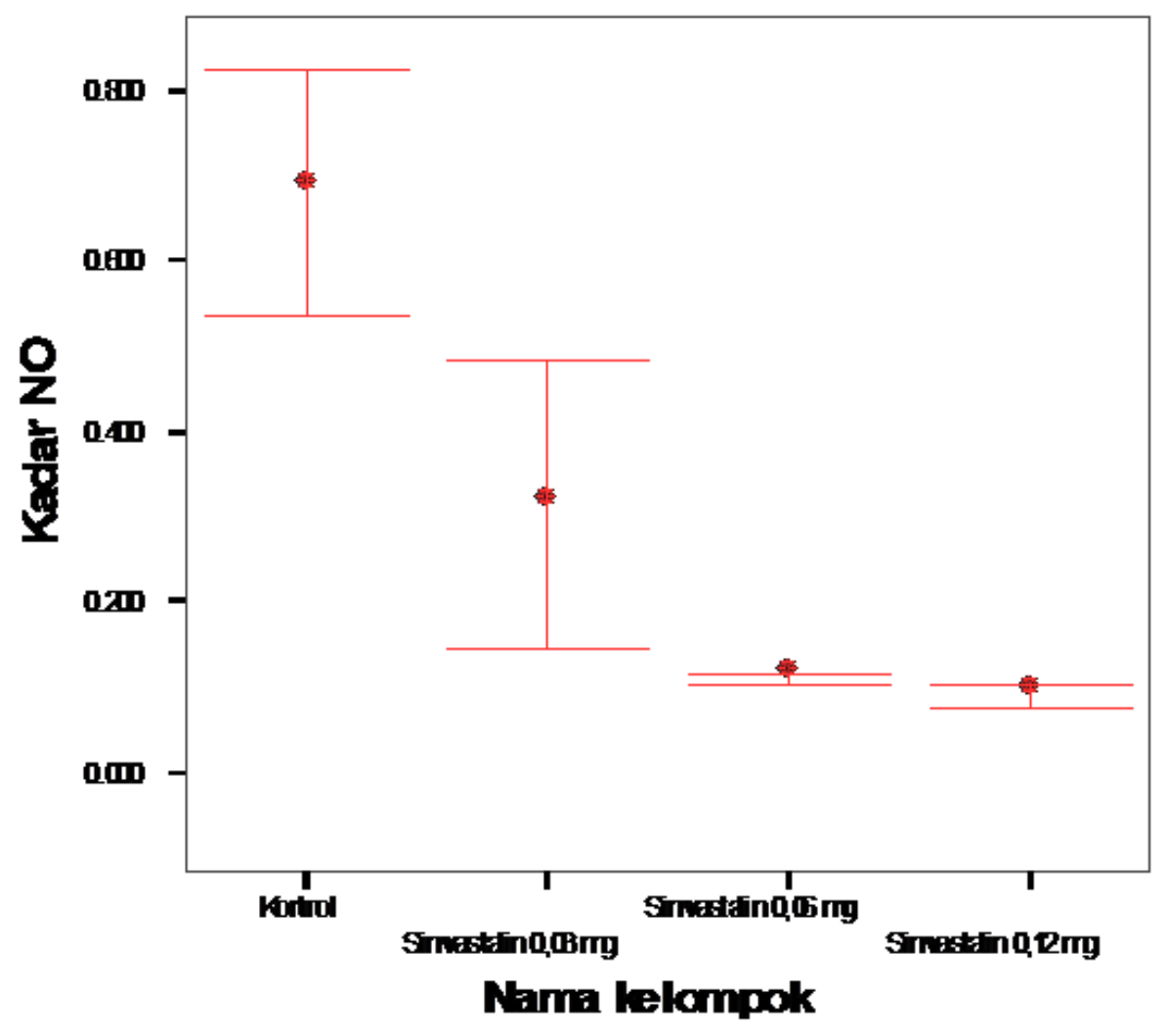

Gambar 1. Grafik error bar kadar NO kelompok penelitian 
kelompok perlakuan K2 dibandingkan kelompok perlakuan K4 $(p=0,122)$, serta kadar NO makrofag intraperitoneal pada kelompok perlakuan K3 dibandingkan kelompok perlakuan K4 $(p=0,101)$.

\section{PEMBAHASAN}

Hasil tersebut di atas sesuai dengan penelitian sebelumnya dimana Yasuda dkk menyatakan bahwa simvastatin menekan TNF- $\alpha$ mencit sepsis. Pada penelitian lain Arnaud dan Chello menyatakan bahwa simvastatain menekan IL-6 dan IL-8. TNF- $\alpha$ merupakan sitokin pertama yang terinduksi setelah stimulasi LPS yang kemudian juga akan menstimulasi IL-1 dan IL-6 pada makrofag, monosit, neutrofil dan sel endotel. Efek supresi simvastatin terhadap IL-6 dan IL-8 dapat secara langsung maupun melalui penghambatan pelepasan TNF- $\alpha$ yang diinduksi oleh LPS. Pada penelitian ini penurunan kadar NO makrofag akibat iNOS tidak teraktivasi dikarenakan efek supresi simvastatin terhadap TNF- $\alpha$ serta IL-6 dan IL-8. ${ }^{17,18,19}$

HMG CoA reduktase mengkatalisis pembentukan mevalonat dari asetil-CoA dan mengatur biosintesis kolesterol. Metabolit mevalonat, terutama farnesyl pyrofosfat, termasuk dalam modifikasi post-translational dari beberapa protein penting. Inhibisi dari HMG CoA reduktase telah menunjukkan dapat menurunkan LPS dan TNF- $\alpha$ yang diinduksi oleh aktivasi NF-kB pada sel mesangial, sel otot polos vaskuler dan sel mononuclear. Lebih lanjut pada makrofag tikus, HMG CoA reduktase inhibitor seperti simvastatin menghambat ekspresi induksi LPS dari sitokin dan iNOS, yang dianggap dimediasi oleh aktifasi NF-kB. Jalur mevalonat dianggap memiliki peranan penting dalam mengatur ekspresi mediasi NF-kB dari sitokin dan iNOS. HMG CoA reduktase inhibitor menghambat peningkatan sitokin inflamasi dan kadar NO, meskipun mekanisme molekuler yang mendasari efek ini masih harus diteliti kembali. ${ }^{15,17}$

Faktor transkripsi NF-кB mempunyai peranan krusial pada proses inflamasi. NF-кB merupakan faktor transkripsi yang akan memicu produksi sitokin. Pemberian LPS akan mengaktifkan NFкВ yang akan meningkatkan produksi mediator inflamasi seperti IL-8, TNF- $\alpha$, intercellular adhesion molecule (ICAM) dan cyclooxygenase-2. Zelvyte dkk menyatakan dalam penelitiannya bahwa simvastatin menghambat aktivasi NF- 
$\mathrm{kB}$, sehingga simvastatin secara signifikan akan menurunkan konsentrasi TNF- $\alpha$ dan IL-6. ${ }^{17}$

Pada pemberian obat seperti simvastatin akan dicari dosis sekecil mungkin yang cukup mampu memberikan efek terapi, sehingga efek samping akibat kelebihan dosis obat dapat dikurangi. Dari penelitian ini dosis $0,03 \mathrm{mg}$ pada mencit yang setara dengan $10 \mathrm{mg}$ sudah mampu menyebabkan penurunan kadar NO makrofag intraperitonel dan tidak berbeda dengan dosis $0,06 \mathrm{mg}$ ataupun $0,12 \mathrm{mg}$. Dosis simvastatin $0,03 \mathrm{mg}$ pada mencit sudah cukup efektif untuk menurunkan kadar NO makrofag intraperitoneal.

Penelitian ini menunjukkan bahwa simvastatin, suatu HMG-CoA reduktase inhibitor, dapat mengurangi peningkatan produksi NO. Hipotesis yang sering berkembang penyebab terjadinya vasodilatasi dan hipotensi selama sepsis bahwa terdapat peningkatan produksi NO karena aktivasi iNOS dan eNOS. Pada penelitian ini ditemukan bahwa terdapat penurunan sesuai dosis dari kadar NO setelah pemberian LPS pada mencit yang diberikan simvastatin. Hasil ini memberi kesan bahwa simvastatin menghambat produksi NO dan efek ini secara teori akibat dari penurunan aktivitas iNOS selama syok endotoksin. ${ }^{15,20}$

NO yang diproduksi oleh makrofag memiliki efek menghancurkan bakteri (killing), sehingga apabila produksi NO berkurang maka akan terjadi penurunan aktivitas killing bakteri oleh makrofag. ${ }^{21}$ Pada sepsis pemberian terapi yang menimbulkan efek penurunan produksi NO harus diikuti oleh pemberian antibiotik yang kuat.

Severe sepsis masih menunjukkan angka mortalitas yang tinggi karena tidak ada terapi tunggal yang telah ditemukan secara sempurna efektif untuk itu. Penelitian lebih lanjut diperlukan untuk menunjukkan efek proteksi dari statin, yang merupakan inhibitor HMG CoA reduktase. ${ }^{15,16,22}$

\section{SIMPULAN}

Simvastatin secara bermakna dapat menyebabkan kadar NO makrofag intraperitoneal mencit yang diinduksi lipopolisakarida menjadi lebih rendah. 


\section{DAFTAR PUSTAKA}

1. Oberholzer C, Oberholzer A, Clare-salzler M, Moldawer LL. Apoptosis in Sepsis: a New Target for Therapeutic Exploration. The FASEB Journal 2001;15:879-92.

2. Paterson RL, Webster NR.Sepsis and the Systemic Inflammatory Responsse Syndrome. R.Coll.Surg.Edinb 2000;178-82.

3. Hotchkiss SR, Karl EI. The Pathophysiology and Treatment of Sepsis.2003;348:138-50.

4. Karl IE. Pathogenesis of Sepsis and Multiorgan Dysfunction. J Cell Biochem 1992;267:10931-44.

5. Hermawan AG. Sitokin yang Berperan dalam SIRS dan Sepsis. SIRS, Sepsis dan Syok Septik (Imunologi, Diagnosis, Penatalaksanaan) 1th ed. Sebelas Maret University Press. 2008; 19-30

6. Vincent JL, Zhang J, Szabo C, Preiser JC. Effect of Nitric Oxide in Septic Shock. Am J Respir Crit Care Med 2000;16(1):1781-5.

7. Chandar A, Enkhbaatar P, Nakano Y, Traber DL. Sepsis: Emerging Role of Nitric Oxide and Selectin. Clinics.2006;61(1):716

8. Greenwood J, Mason JC. Statins and the Vascular Endothelial Inflammatory Response. Trends Immunol 2007; 28: 8898

9. Katzung BG. Agents Used in Hyperlipidemia. In Basic and Clinical Pharmacology $10^{\text {th }}$ Ed. Mc Graw-Hill. New York.2007. ebook

10. Greenwood J, Steinman L, Zamvil SS. Statin Therapy and Autoimmune Disease: from Protein Prenylation to
Immunomodulation. Nat Rev Immunol 2006; 6: 358-70

11. Gao F, Linhartova L, Johnston A. Thickett DR. Statins and Sepsis. Br J Anaesth 2008; 100: $288-98$

12. Almog YM, Shefer AM, Novack VM. Prior Statin Therapy is Associated with a Decreased Rate of Severe Sepsis [Article]. Circulation 2004; 110: 880-5

13. Fortier AH, Falk LA. Isolation of Murine Macrophage. Curr Protoc Immunol 2001; 14: $1411-9$

14. Davies JQ, Gordon S. Isolation and Culture of Murine Macrophages. Method in Molecular Biology Clifton NJ 2005; 290: 91 $-103$

15. Ando $H$, Takamura $T$, Ota $T$, Nagai $Y$, Kobayashi K. Cerivastatin Improves Survival of Mice with LipopolysaccharideInduced Sepsis. J Pharmacol Exp Ther 2000; 294: 1043-6

16. Mahley RW, Bersot TP. Drug Therapy for Hypercholesterolemia and Dyslipidemia. In Brunton LL, Lazo JS, Parker KL. Goodman \& Gilman's The Pharmacological Basis of Therapeutics $11^{\text {th }}$ Ed. McGraw-Hill. New York 2006. Ebook

17. Yasuda H, Yuen PS, Hu X, Zhou H, Star RA. Simvastatin Improves Sepsis-Induced Mortality and Acute Kidney Injury via Renal Vascular Effects. Kidney Int 2006; 69: $1535-42$

18. Arnaud C, Burger F, Steffens S. Statins Reduce Interleukin-6-Induced C-Reactive Protein in Human Hepatocytes: New Evidence for Direct Antiinflammatory Effects of Statins. Arterioscler Thromb Vasc Biol 2005; 25: 1231-6 
19. Chello M, Patti G, Candura D. Effects of Atorvastatin on Systemic Inflammatory Response after Coronary Bypass Surgery. Crit Care Med 2006; 34: 660-7

20. Merx MWM, Liehn EAM, Graf JM. Statin Treatment after Onset of Sepsis in a Murine Model Improves Survival [Article].
Circulation 2005; 112: 117-24

21. Abbas AK. Basic Immunology: Functions and Disorders of the Immune System. 2nd ed. Philadelphia: Elsevier Saunders Companies.2007; p175-85.

22. Merx MWM, Liehn EAM, Janssens UM. HMG-CoA Reductase Inhibitor Simvastatin Profoundly Improves Survival in a Murine Model of Sepsis [Report]. Circulation 2004; 109: 2560-5 